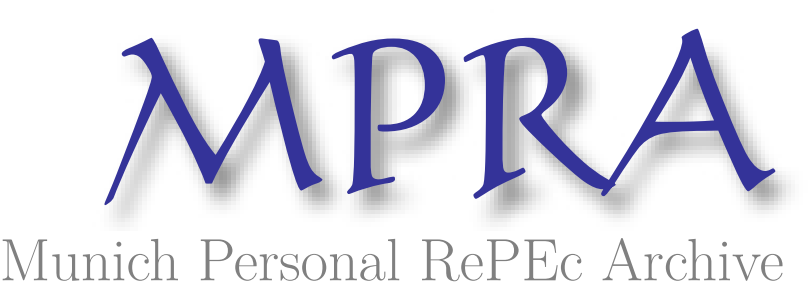

\title{
Political Economy of Argentine Sovereign Debt and the Holdouts Problem
}

Swamy, Vighneswara

Institute of Economic Growth Delhi

2014

Online at https://mpra.ub.uni-muenchen.de/58474/

MPRA Paper No. 58474, posted 10 Sep 2014 14:28 UTC 


\title{
Political Economy of Argentine Sovereign Debt and the Holdouts Problem
}

\author{
By \\ Vighneswara Swamy Ph.D* \\ vs@iegindia.org
}

There seems to be no end to the sovereign debt woes of Argentina in the near future, as the 'holdouts' are accused of turning out to be vultures and are hell bent on their pound of flesh. The crisis has resurfaced as the Argentine President Cristina Fernandez de Kirchner, having been advised by her country's lawyers, to intentionally default on dollars of its sovereign debt in order to force a renegotiation of the debt and to take the case away from American judges. This is the second such default by Argentine in the last thirteen years. Expert analysts term this a bad advice, and Argentina continues to follow it. Even if Argentina nudges ahead to restructure all its sovereign debt outside US to avoid the jurisdiction of the US courts, it might further deepen its status as a pariah country. The debt crisis has indeed compounded the problems for Argentina as it is already imbued with an array of macroeconomic woes caused by the artificially overvalued currency leading to stubbornly high inflation, state subsidies that are sapping resources, and an abysmal business climate that has seen investment all but dry up. If the crisis is not resolved adequately, there is every danger of driving the Argentine economy into structural economic mess. Though, Argentina has had seven defaults since 1827 to 2001 that were mostly selfinflicted, the 2014 default seems to be due to a sudden shift in the international sovereign debt regime fvaouring the 'hold-outs' governed by US laws. The puzzle is how did it all happen? How can it be resolved? What is the way forward? What are the lessons to the other developing countries?

\section{The Crisis and the Consequent Default}

The Achilles' heel of Argentine economic strategy lies with its approach that has long relied on fiscal largesse as a basic policy tool, covering its shortfalls by expanding the money supply. This resulted in recurring bouts of high inflation and indebtedness, followed up by ephemeral efforts to stabilize prices. En route the end of $20^{\text {th }}$ century, Argentina experienced hyperinflation and brought in the new regime with the Menem-Cavallo cure for chronic inflation, the now infamous "convertibility plan." Though, at first convertibility plan worked well, cracks in Argentine economic policy began to resurface due to the large fiscal deficits both at the 
provincial and national levels. Compounded by the practice of rolling over, the sovereign debt began to grow from 1993. The overvalued Argentine Peso soon got overvalued reducing the country's international competitiveness followed by the typical declines in public revenues to service the mounting debt. Grappled with this indefensible state of affairs compounded with falling international credibility, financial panic, and political unrest, Argentina became defaulter in 2001 with the debt mushrooming from $45 \%$ of GDP in 2000 to $166 \%$ in 2002 . The default totaled USD 97.6 billion with dues to private investors (USD 81.8 billion), the Paris Club countries (USD 6.3 billion) and the IMF (USD 9.5 billion) among other multilateral obligations. A sovereign default implies that the government is no longer willing or capable of paying the debt it has legally incurred in the international markets.

\section{Restructuring Saga}

Hit with the financial crisis, Argentina had to suffer capital flight and steep devaluation of currency leading to sudden evaporation of its wealth. As poverty and unemployment skyrocketed, leading to street protests and political unrest, Argentina began its efforts to restructure its sovereign debt in 2002. It faced three significant complexities: (i) negotiating an arrangement with private creditors, (ii) reschedule its obligations towards the Paris $\mathrm{Club}^{1}$, and (iii) reengage the IMF. Again, the problems began to compound with the Argentina choosing to engage in an antagonistic, hard line, and self-destructive behaviour rather than engage creditors in a negotiation, by way of insisting on a large write-down of principal for private creditors and postponing action on Paris Club and IMF debt. After protracted negotiations that lead to a standoff, eventually, Argentina suspended its agreement with the IMF and approached the Securities and Exchange Commission (SEC) with an offer to settle with private creditors with the so-called "Ley Cerrojo (Lock Law)" that prohibited the government from making any kind of future offer on better terms, and suspended any future payments on the untendered debt.

In 2005, it went ahead with its controversial bond exchange programme anticipating a final settlement with the private investors on the USD 81.8 billion debt plus the past due interest of USD 20.8 billion totaling a massive USD 102.6 billion. This unilateral offer by Argentina was

\footnotetext{
${ }^{1}$ The Paris Club is a voluntary group of 19 creditor nations who have, informally agreed to act with a common approach to negotiate debt relief for such developing countries that are unable to meet their external obligations.
}

* Dr. Vighneswara Swamy is currently with Institute of Economic Growth Delhi as Senior Fellow. 
accepted by $76 \%$ of the creditors. Typically, successful restructuring negotiations have been with more than $90 \%$ of the creditors agreeing for the offer. Critics comment that had Argentina modified the offer, the deal would have been less expensive in the long run and would have garnered over $90 \%$ of the bondholders to accept the offer. With a large holdouts (24\% of creditors), the restructuring process headed for furthermore complicacies. Nevertheless, out of USD 81.8 billion (face value) debt, Argentina could exchange USD 62.3 billion for $\$ 35.2$ billion of new bonds leaving the past due interest unaddressed. Further, debt restructuring remained incomplete as USD 18.6 billion of bonds were not tendered and remained in dispute along with accrued interest, USD 6.3 billion of Paris Club arrears, and USD 9.5 billion of IMF debt.

Buoyed by the 2003-2008 economic recovery, Argentina in a comfortable financial shape again embarked on sovereign debt restructuring in 2010 and exchanged USD 12.4 billion of the eligible USD 18.4 billion in bonds with 67.7\% participation, leaving behind USD 6 billion untendered. Thus, Argentina contended that a "successful" exchange would be one that exceeded a $60 \%$ participation rate because it would allow for a total participation rate, including the 2005 exchange, of over $90 \%$ of defaulted debt. If executed through mutually agreed negotiations, this threshold would have been adequate to resolve the default, allowing Argentina eventually to participate in international credit markets.

\section{The Holdout's Problem}

Argentina states that it is in arrears for USD11.2 billion to the holdouts worldwide (including $\$ 6.8$ billion in principal past and coming due, and $\$ 4.4$ billion in past due interest through December 2010). On the contrary, holdout creditors dispute that this number could be USD 15 billion by 2013, of which USD 1.3 billion is being litigated by hedge funds in U.S. courts. While Argentina continues to argue that the restructuring succeeded the extensive negotiations, they cannot be construed as mutually agreed solutions as the bondholders had to accept or reject the offers with the alternative being the promise of no restitution at all. Holdouts have challenged the outcome in various courts as illegal under the pari passu provision of the bond contracts.

Now the issue of intense debate among the legal circles is that of interpretation of the equal treatment provision of the bond contracts. The US district court found in favor of holdout 
creditors who argued that paying the exchange bondholders while repudiating the holdout debtors has been a breach of this provision. An appeals court ruling in August 2013 in the Argentina v. NML Capital case, determined that holdouts should be repaid the full face value. In October 2013, the US Supreme Court affirmed the decision without comment. On the contrary, courts in Belgium, France, and Germany have ruled in favour of Argentina based on the equal terms clause. Argentina, on the other hand, claims that it cannot pay the holdouts because of the Rufo clause (Right on Future Offers) in the 2005 and 2010 debt negotiations would require the country to pay all of the bondholders the same amount of money. If Argentina pays the holdouts, it would also have to pay current bondholders their back interest, which would negate the very edifice of debt restructuring and could the cost of the Rufo clause could be around USD 120 billion. The Rufo clause holds that in case Argentina voluntarily makes an offer to exchange or purchase the bonds held by the holdouts, it would have to make the same offer as well to the bondholders who already exchanged their Argentinean debt at a lower price in 2005 and 2010.

The other important dimension of the Argentinean default resolution mess has been the role played by the NML Capital Limited, a Cayman Islands-based offshore unit of Paul Singer's Elliott Management Corporation. Accused by Argentina as a vulture fund, NML capital purchased the majority of their holdings in 2008 by paying around USD 49 million for a series of bonds of face value USD 220 million. With the subsequent boom in the market, the worth has grown to USD 832 million by 2014. NML Capital in turn has formed the American Task Force Argentina, a lobbying group against Argentine bond restructuring efforts, and sued to enjoin Argentina's ongoing payments to the bondholders who had participated in the earlier restructurings. NML capital lead by its aggressive founder, Paul Singer of US hedge fund Elliott Associates has been active in attempts to seize Argentine government assets abroad - notable ones being the attachment of Central Bank deposits in the Federal Reserve Bank of New York, the presidential airplane, and the ARA Libertad (an Argentine Navy training frigate). Further, the dispute has limited Argentina's access to foreign credit markets as well.

\section{Blurred Sovereign Rating}

Argentina faces another problem of unclear sovereign ratings by the global ratings agencies. Following the recent 2014 ruling by a District Court Judge Thomas Griesa that 
Argentina could not pay its bondholders unless Argentina also paid the holdouts in full has affected the New York Law Argentine bonds. In view of this, while, Standard \& Poor's has put Argentina in the 'selective default', Fitch has rated it as 'restricted default'. Moody's has put the Argentine bonds in 'Junk' category. This might generate negative externalities for the private sector and real economic activity, as sovereign downgrades lead to greater increases in the cost of debt and greater decreases in investment and leverage of firms. Now the third largest economy of the Latin America has approached the International Court of Justice (ICJ) in The Hague to take action against the United States over an alleged breach of its sovereignty as it defaulted on its debt.

\section{The Possible Way Out}

Some economists argue that Argentina should simply pay the "holdout" creditors and get over with, or at least try to haggle over a rate that works for both parties. But such a move of paying the court-ordered $\$ 1.5$ billion to plaintiffs could expose Argentina to upward of $\$ 15$ billion in additional claims from other holdouts, and deplete the country's $\$ 28$ billion in foreign reserves to its less than a half, which Argentina most probably cannot afford to. In another interesting development, the private sector has initiated to intervene as the Association of Bankers of Buenos Aires (ADEBA) was actively involved in talks with the holdouts in New York and was rumored to have offered to buy the debt from the vulture funds in a series of payments. In another development, international banks have approached private investors with a stake in Argentina's financial stability to buy the disputed debt and allow Argentina to resume servicing its bonds. Besides, Argentina has taken steps towards normalizing the economy and relations with the outside world. Moreover, this 2014 default is more of a technical default not because of the inability; Argentina should not be in a precarious position. At only one third of GDP, Argentina's sovereign debt is quite sustainable. In the short term, there might not be any severe noticeable impacts on the real economy, but it does not augur well for the long term. IMF needs to take a proactive stance to resolve the situation. As economist Roubini argues, the root cause for defaults lie in the government's state-centric economic policies and is scaring away investors and consumers alike. According to Roubini, Argentina has moved away from marketoriented policies with imports substitution protectionist measures; national control over natural resources; a more predominant role for state companies and banks and discouraging foreign 
investments and the influx of capital. He terms this a form of "state capitalism" which makes the country more vulnerable to any domestic or international turmoil.

On a theoretical perspective, typically, an inherent characteristic of global financial markets is that debtors and creditors systemically tend to overshoot, periodically giving rise to unsustainable debt situations that end up in a liquidity crisis or a default in the worst case. Sovereign defaults necessitate for (i) a better preventive regulation and/or (ii) better crisis settlement mechanisms. With the proliferation of Collective Action Clauses (CACs), there is at present, one instrument at work that facilitates coordination of the creditors of single bonds in a default situation. While the IMF's Sovereign Debt Restructuring Mechanism (SDRM) and the International Debt Framework (IDF) are more pragmatically oriented, the Fair and Transparent Arbitration Process (FTAP) is considered an ideal-type solution, in the sense that it is more inclusive, equitable, and maybe even more effective than all the other approaches but faces significant obstacles regarding its implementation.

\section{Concluding Remarks}

Argentina has become almost as infamous for sovereign debt defaults as it is for its failures in the world cup soccer. That apart, the 2014 sovereign default of Argentina poses unsettling questions for policymakers. It is a fact that the country's periodic debt crises are often the result of self-destructive macroeconomic policies. However, in this case, the default is triggered by a significant shift in the international sovereign debt resolution mechanism; particularly the shift favors hard line creditors in bond issuances governed by US law. It is unfortunate that there is no steadfast cooperation from the US to IMF in establishing credible debt restructuring mechanism at place to ensure macroeconomic and global financial stability. Given the global economic scenario where there is slowing of emerging market growth and rising external debt, this trend of new interpretations by the judicial adjudicators make the future rescheduling more difficult and do not abode well for global financial stability. The take away for the developing countries from the Argentine sovereign debt trauma is to greatly deepen their domestic debt markets in the long run. Though domestic borrowing is not a panacea, but, to some extent, it can enable the countries stay away from the vultures in the global markets.

* Dr. Vighneswara Swamy is currently with Institute of Economic Growth Delhi as Senior Fellow. 